"The psychological career resources and organizational commitment foci of South African workforce"

AUTHORS Rebecca Tladinyane

Rebecca Tladinyane (2016). The psychological career resources and

ARTICLE INFO organizational commitment foci of South African workforce. Problems and Perspectives in Management, 14(1-1), 168-175. doi: 10.21511/ppm.14(11).2016.04

DOI http://dx.doi.org/10.21511/ppm.14(1-1).2016.04

RELEASED ON Monday, 11 April 2016

JOURNAL

"Problems and Perspectives in Management"

FOUNDER

LLC "Consulting Publishing Company "Business Perspectives"

NUMBER OF REFERENCES

0

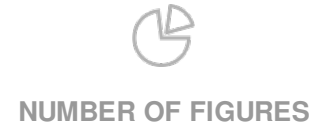

0

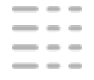

NUMBER OF TABLES

0

(C) The author(s) 2022. This publication is an open access article. 
Rebecca Tladinyane (South Africa)

\title{
The psychological career resources and organizational commitment foci of South African workforce
}

\begin{abstract}
One of most critical issues facing organizations today is how to retain employees they want to keep. The study examines the relationship dynamics between employees' psychological career resources (measured by the Psychological Career Resources Inventory) and their organizational commitment foci (measured by the Organization-Related Commitment Scale). A quantitative survey is conducted involving a non-probability purposive sample of predominantly black females employed at managerial and staff levels $(\mathrm{N}=318)$ in the field of industrial and organizational psychology. The findings provide valuable indicators for the design of career development practices aimed at retaining valuable staff.
\end{abstract}

Keywords: career development, organizational commitment foci, psychological career resources, retention. JEL Classification: M12, J24.

\section{Introduction}

Retention of valuable staff is critical for South African Business. Globalization has not only helped the organizations to look for talented employees but also to retain their talented employees (Mahal, 2012). Employers struggle to retain their talented staff due to shortage of experienced candidates and aggressive recruitment tactics by others in the highly competitive era. In order to uplift South Africa to the next competitive landscape, organizations require employees' cooperation, self-sacrifice and extra effort (May, Werner and Theron, 2014).

The present study focused on the psychological career resources and the psychological attachment or commitment to the organization. By identifying the relationship between these variables, recommendations can be made to enhance organizational careerdevelopment support practices as a critical element in the retention of valuable staff. The retention of employees seems to be influenced by psychological attributes, that include individuals' ability to adapt to and deal proactively with the changing and uncertain nature of their careers in the contemporary world of work (Ferreira, 2012; Savickas, 2011; Savickas, Nota, Rossier, Dauwalder, Duarte and Guichard, 2009).

In the retention context, organizations thus need to take into consideration the changing priorities of employees and what attracts employees to their jobs, careers, work, occupations and the organization itself. Organizational commitment has been extensively studied in the retention context (Ferreira, 2010; Lumley, 2009). Employees' commitment is important because high levels of commitment lead to favorable organizational outcomes. According to Dixit and Bhati (2012) employee commitment reflects the extent, to which employees are identified with an organization and commitment to its goals.

(C) Rebecca Tladinyane, 2016.

Rebecca Tladinyane, D.Litt. et. Phil., Senior Lecturer, Department of Industrial and Organizational Psychology, University of South Africa, South Africa.
A committed employee is perceived to be the one, who stays with the organization in turbulent times, attends work regularly, protects the company asserts and shares organizational goals (Meyer and Allen, 1997). Organizational commitment is regarded as a particularly powerful predictor of employee turnover, because an employee's level of commitment is dependent on how they interpret and make sense of their work context (Bentein, Vandenberghe, Vandenberg, and Stinglhamber, 2005; Meyer and Allen, 1997).

The aim of this research was to determine the relationship between individuals' psychological career resources and their organizational commitment foci. An understanding of the variables relating to the internal career such as people's psychological career resources and organizational commitment foci may influence their turnover intentions and be essential for organizations to consider in the retention of their staff.

Although some research has been done on the relationship between psychological career resources and organizational commitment (Ferreira, 2010; 2012), there is little theoretical and empirical information on how employees' psychological career resources influence organizational commitment foci in the South African context.

The current study thus potentially adds to the retention and career literature by fostering an understanding, of how people's psychological career resources and organizational commitment foci influence the retention of employees in the South African organizational context.

\section{Literature review}

1.1. Psychological career resources. Individuals' range of psychological career resources consists of career preferences, career values, attitudes and competencies that go beyond work-related technical skills (Coetzee, 2008). Individuals who possess a wide range of psychological career resources will likely be able to deal with and adapt to changing 
career circumstances and demonstrate high levels of employability (Fugate, Kinicki and Ashforth, 2004; Griffin and Hesketh, 2005; McArdle, Waters, Briscoe and Hall, 2007).

A well-developed psychological career resources profile enables individuals to proactively manage their career development (Coetzee, 2008; Ebberwein, Krieshok, Ulven and Prosser, 2004; Van der Heijde and Van der Heijden, 2006) and has been shown to increase their affective commitment to the organization (Ferreira, 2010). The constructs of psychological career resources are career preferences, career drivers, career enablers and career harmonizers (Coetzee, 2008).

- Career preferences and values guide the decisions individuals make in terms of their long-term career choices (Coetzee, 2008). The meaningfulness of a career to the individual is influenced by what he or she prefers and values (Kim, 2005). These two psychological career resources guide the long-term decisions that individuals make regarding their career, and are the definitive factors in the meaning of a career to an individual.

- Career drivers refer to the inner forces that determine what an individual wants or needs from his or her employment (Coetzee, 2008). Career drivers consist of people's career purpose, career directedness and career-venturing attitudes. These attitudes energize people and motivate them to experiment with new or alternative careers and employment possibilities that are based on their views of the possible selves they could become or the possible working roles they could experience (Coetzee, 2008).

- Career enabler is a set of skills (practical, creative or self/other skills) that allows an individual to perform tasks relating to his or her career development well and helps him or her to achieve the desired and expected career outcomes.

- Career harmonizers comprise people's selfesteem, behavioral adaptability, emotional literacy and social connectivity. These psychological career meta-capacities act as promoters of flexibility and resiliency, and as controls by keeping the career drivers in balance so that people do not go overboard (or burn themselves out) in the process of pursuing and reinventing their careers (Coetzee, 2008).

Different characteristics of a person's psychological career resources have to be in a state of equilibrium, to allow development of an individual as a whole, in order to ensure proactive career behavior. This balance is an indication of awareness and independent career behavior, which are intrinsically driven by the individuals' psychological career resources.
1.2. Organizational commitment foci. Commitment research has focused on commitment to the organization, but now there is widespread recognition that there are different foci of commitment to which individuals can feel commitment (Cohen, 2003; Wasti and Onder, 2009). Commitment has evolved as a wide range of types (e.g. engagement, attachment, commitment, involvement) within a wide spectrum of foci (e.g. work, job, career, occupation and organization), while studies on commitment varied between the categories of behavior, attitude and motivation (Roodt, 2004).

For the context of this study organizational commitment foci refers to cognitive predisposition towards a particular focus insofar as this focus has the potential to satisfy needs, realize value and achieve goals (Roodt, 1997). According to Roodt (1997) five foci related to organizational commitment are: work, job, career, occupation and organization.

- Work foci refer to the loyalty of employees towards work itself. People who are strongly loyal to their work make sure that it is their responsibility to make sure that they add value to their employing organization (Aryee, Chay and Chew, 1994; Meyer and Allen, 1997).

- Career foci refer to the identification and involvement of a person in his or her occupation (Mueller, Wallace and Prince, 1992). Work environments and the pace of careers in organizations have led employees to exhibit more commitment to their careers and perhaps less or conditional commitment to their organization (Noordin, Williams and Zimmer, 2002).

- Job foci involve a person's dedication to a moderately temporary set of objective task requirements (Colarelli and Bishop, 1990). This implies that the individual will be dedicated to tasks that come with the roles of the job.

- Occupational foci is seen as the commitment to an identifiable and specific line of work that an individual engages in to earn a living at a given point in time (Lee, Carswell and Allen, 2000).

- An individual with organizational foci as his or her focus is willing to remain with organization by putting more effort into the attainment of the organizational goals. The loyalty of the individual will be based on their acceptance of values and goals as their own.

Organizational commitment has been shown to be positively related to person-organization fit (Valentine, Godkin and Lucero, 2002). This implies that, should conflict arise between personal characteristics of employees, such as those indicated by their psychological career resources and the attributes of their organizations, low organizational 
commitment, job stress and turnover will be experienced (Judge and Ferris, 1992; Peterson, 2003; Schneider, Goldstein and Smith, 1995).

1.3. Psychological career resources and organizational commitment foci. Coetzee (2008) proposes that individuals with well-developed psychological career resources are able to plan their careers, make certain decision based on this planning, explore new opportunities and have the confidence to implement these decisions in order to perform the activities needed to successfully accomplish their career objectives. People who have access to personal (psycho-social) resources at work, tend to have a greater sense of self-worth, which places them in a better position to invest significant time and effort in pursuing their work activities, and they are thus more likely to achieve career success (Hobfoll, 2002), which in turn may enhance their levels of commitment.

Employees who feel strongly committed may define their relationships with their employers as long term, and have lower intent to quit, as opposed to employees who have lower levels of commitment to their organizations (Mallol, Holtom and Lee, 2007; Meyer and Allen, 1997). Since the psychological career resources include the positive and negative selfappraisals, individuals make with regards to the planning and management of their career development, it is expected that the psychological career resources profile might explain commitment foci of the individuals.

An individual with a well-developed psychological career resources profile might show stronger commitment to different organizational foci. Strong commitment to different foci might ensure, that the individual remains with the organization due to the perceived psychological contract between the employer and the employee. As found by Ferreira, Basson and Coetzee (2010), the individual might be affectively more committed or psychologically connected to the organization. The individual might refrain from leaving the organization due to the perceived costs associated with leaving the organization. The individual might also feel a strong sense of responsibility towards the organization, which in turn might influence the decision to leave the organization.

Given the preceding discussion, the following is hypothesized:

Hypothesis 1: Psychological career resources are positive related to organizational commitment foci.

\section{Method}

2.1. Research approach. A cross-sectional quantitative survey design was used to achieve the research objective.
2.2. Participants. A non-probability purposive sample of employed adults $(\mathrm{N}=318)$ at managerial and staff levels in the field of industrial and organizational psychology participated in the study. Overall, the majority of the participants were blacks $(76 \%)$ and females $(77 \%)$ in the early adulthood life stage and establishment phase of their careers (2640 years). The participants occupied staff level (57\%) and managerial level (43\%) positions in the South African services industry.

2.3. Measuring instruments. The Psychological Career Resources Inventory (PCRI), developed by Coetzee (2008), was used to measure the participants' psychological career resources. The PCRI (Coetzee, 2008 ) is a self-rated multi-factorial measure containing 64 items and five subscales (career preferences, career values, career enablers, career drivers and career harmonizers). The inventory measures 15 constructs in total. A six-point Likerttype scale was used for subject responses to each of the 64 items. Cronbach alpha coefficients for each subscale range from .71 to .88. Studies conducted by Coetzee (2008), Ferreira (2010, 2012) confirmed the internal consistency reliability and construct validity of the PCRI in the South African context.

The participants' organizational commitment foci were measured by using the Organization-related Commitment Scale (Roodt, 1997). The Organizationrelated Commitment Scale (OCS) is a self-report questionnaire which includes 38 items, measuring the participants' commitment to work foci, job foci, occupational foci, career foci and organizational foci. A five-point Likert-type scale was used for subject responses to each of 38 items. Acceptable construct validity and internal consistency reliabilities of $\geq .90$ were reported by Roodt (1997), Storm and Roodt (2002), and Pretorius and Roodt (2004).

2.4. Procedure. Before the study was conducted, ethical protocol was followed. Data were collected by mailing questionnaires to a purposive sample of employed adults enrolled for honors level distance learning studies in the field of industrial and organizational psychology in a particular year of study. Participation was voluntary and the respondents gave their permission for the results to be used for research purposes only. The anonymity and confidentiality of all participants was ensured.

2.5. Statistical analysis. Descriptive (means, standard deviations and reliability analyses) and canonical correlation analysis were performed to achieve the objective of the study.

\section{Results}

3.1. Descriptive statistics. Means, standard deviations and internal reliability for the variables are shown in Table 1. 
Acceptable internal consistency reliability coefficients were obtained for the two measuring instruments except for the OCS work foci subscale $(\alpha=.04)$. It was therefore decided to exclude the work foci subscale from the statistical analyses.

Table 1. Descriptive statistics: means, standard deviations and reliability summary statistics (PCRI and OCS $)(\mathrm{N}=318)$

\begin{tabular}{|l|c|c|}
\hline \multicolumn{1}{|c|}{ Scale dimension } & $\mathrm{M}(\mathrm{SD})$ & $\mathrm{a}$ \\
\hline PCRI (psychological career resources) & & \\
\hline Career preference & & \\
\hline Stability/expertise & $5.30(.64)$ & .67 \\
\hline Managerial & $4.48(1.16)$ & .85 \\
\hline Variety/creativity & $5.05(.85)$ & .83 \\
\hline Independence/autonomy & $4.74(.91)$ & .70 \\
\hline Career values & & \\
\hline Growth/development & $5.49(.66)$ & .71 \\
\hline Authority/influence & $4.97(.4 .97)$ & .76 \\
\hline Career enablers & & \\
\hline Practical/creative skills & $4.63(.91)$ & .76 \\
\hline Self/other skills & $4.93(.79)$ & .78 \\
\hline Career drivers & & \\
\hline Career purpose & $5.34(.72)$ & .78 \\
\hline Career directedness & $4.68(.86)$ & .72 \\
\hline Career venturing & $4.76(.94)$ & .68 \\
\hline Career harmonizers & & \\
\hline Self-esteem & $5.09(.81)$ & .77 \\
\hline Behavioral adaptability & $4.92(.79)$ & .83 \\
\hline Emotional literacy & $4.52(.96)$ & .76 \\
\hline Social connectivity & $5.04(.76)$ & .77 \\
\hline OCS & & \\
\hline Work foci & $3.75(.58)$ & .04 \\
\hline Job foci & $3.68(.50)$ & .67 \\
\hline Occupational foci & $3.78(.60)$ & .65 \\
\hline Career foci & $3.81(.58)$ & .82 \\
\hline Organizational foci & $3.18(.74)$ & .93 \\
\hline
\end{tabular}

3.2. Correlational statistics. The relationship between the variables was calculated by means of Pearson product-moment correlations. These correlations allow the researcher to identify the strength and direction of the relationship between each of the variables of each instrument.

As shown in Table 2, significant positive correlations were obtained between most of the PCRI variables and the OCQ commitment foci. Table 2 shows that the PCRI career preference managerial relates positively to the following three OCQ variables: job foci, occupational foci and career foci. The PCRI career preference variety/creativity relates positively to the OCQ career foci variable. The PCRI career preference independence/autonomy relates positively to occupational foci and career foci.

In terms of the PCRI career values, growth/development variable relates positively to occupational foci and career foci. The authority/influence PCRI variable relates positively to occupational foci and career foci.

The PCRI career enabler practical/creativity relates positively to occupational foci, career foci and organizational foci. Self/other skills relate positively to occupational foci, career foci and organizational foci.

The PCRI career driver career purpose relates positively to career foci. Positive correlations are also observed between the PCRI career driver, career directedness and occupational foci, career foci and organizational foci. The PCRI career driver, career venturing relates positively to job foci, occupational foci and career foci.

The PCRI career harmonizers, self-esteem and behavioral adaptability relate positively to occupational foci. Self-esteem and behavioral adaptability relate positively to career foci. The career harmonizers, behavioral adaptability, emotional literacy and social connectivity relate positively to organizational foci.

Table 2. Pearson product-moment correlations: PCRI and OCQ $(\mathrm{N}=318)$

\begin{tabular}{|l|c|c|c|c|}
\hline \multicolumn{1}{|c|}{ PCRI scale } & $\begin{array}{c}\text { Job } \\
\text { foci }\end{array}$ & $\begin{array}{c}\text { Occupational } \\
\text { foci }\end{array}$ & $\begin{array}{c}\text { Career } \\
\text { foci }\end{array}$ & $\begin{array}{c}\text { Organizational } \\
\text { foci }\end{array}$ \\
\hline Career preferences & & & & \\
\hline Stability/expertise & 0 & 0 & 0 & 0 \\
\hline Managerial & + & + & + & 0 \\
\hline Variety/creativity & 0 & 0 & + & 0 \\
\hline Independence/autonomy & 0 & + & + & 0 \\
\hline Career values & & & & \\
\hline Growth/development & 0 & + & + & 0 \\
\hline Authority/influence & 0 & + & + & 0 \\
\hline Career enablers & & & & + \\
\hline Practical/creative skills & 0 & + & + & + \\
\hline Self/other skills & 0 & + & + & + \\
\hline Career drivers & & & & + \\
\hline Career purpose & 0 & 0 & + & 0 \\
\hline Career directedness & 0 & + & + & + \\
\hline Career venturing & + & + & + & 0 \\
\hline Career harmonizers & & & & + \\
\hline Self-esteem & 0 & + & + & + \\
\hline Behavioral adaptability & 0 & + & + & + \\
\hline Emotional literacy & 0 & 0 & 0 & + \\
\hline Social connectivity & 0 & 0 & 0 & + \\
\hline
\end{tabular}

Notes: "+" - Small effect, "0" - No effect.

3.3. Multiple regression analysis: PCRI and OCS. Table 3 shows that the regression of the PCRI variables on the OCQ occupational foci variable produced a statistically significant model $(F=1.70$; $p \leq .01$ ), accounting for $\left(R^{2}=.03\right) 3 \%$ (small practical effect) of the variance in the occupational foci variable. Only the PCRI career directedness variable $(\beta=.21)$ contributed in explaining the variance in the occupational foci variable. 
Table 3 further shows that the regression of the PCRI variables on the career foci variable produced a statistically significant model $(F=5.29 ; p \leq .01)$, accounting for $\left(R^{2}=.17\right) 17 \%$ (moderate practical effect) of the variance in the career foci variable. The PCRI social connectivity variable $(\beta=-.28)$ and managerial career preference variable $(\beta=.22)$ contributed the most to explaining the variance in the career foci variable. The stabiity/expertise $(\beta=-.13)$ and social connectivity $(\beta=-.28)$ variables contributed negatively in explaining the variance in the career foci variable. Table 3 also shows that the regression of the PCRI variables on the organizational foci variable produced a statistically significant model $(F=2.13$; $p \leq .05$ ), accounting for $\left(R^{2}=0.05\right) 5 \%$ (small practical effect) of the variance in the organizational foci variable. The PCRI career directedness variable $(\beta=$ .23) and managerial career preference variable $(\beta=$ .17) contributed positively in explaining the variance in the organizational foci variable.

Table 3. Multiple regression analyses: PCRI and OCQ

\begin{tabular}{|c|c|c|c|c|c|c|c|c|}
\hline Variable & \multicolumn{2}{|c|}{ Unstandardized coefficient } & Standardized coefficient & $t$ & $\mathrm{p}$ & $\mathrm{F}$ & Adjusted R square & $\mathrm{R}$ \\
\hline \multirow{3}{*}{ OCQ occupational foci (constant) } & $B$ & $S E B$ & \multirow{3}{*}{ B } & & & & & \\
\hline & 14.63 & 1.80 & & 8.14 & $.000^{* *}$ & 1.70 & $.03^{* *}$ & .28 \\
\hline & & & & & & & + & \\
\hline Career drivers: career directedness & .18 & .06 & .21 & 2.88 & $.004^{* *}$ & & & \\
\hline \multirow{3}{*}{ OCQ career foci (constant) } & B & $S E B$ & \multirow{3}{*}{ B } & & & & & \\
\hline & 16.13 & 2.08 & & 7.75 & $.000^{* *}$ & 5.29 & $.17^{\star \star}$ & .46 \\
\hline & & & & & & & ++ & \\
\hline Career preferences: stability/expertise & -.15 & .08 & -.13 & -1.92 & $.05^{*}$ & & & \\
\hline Career preferences: managerial & .18 & .06 & .22 & 3.20 & $.00^{*}$ & & & \\
\hline Career values: growth/development & .31 & .14 & .16 & 2.14 & $.03^{*}$ & & & \\
\hline Career harmonizers: self-esteem & .18 & .06 & .19 & 2.81 & $.01^{*}$ & & & \\
\hline Career harmonizers: social connectivity & -.34 & .09 & -.28 & -3.77 & $.000^{* *}$ & & & \\
\hline \multirow{3}{*}{ OCQ organizational foci (constant) } & $B$ & $S E B$ & \multirow{3}{*}{ B } & & & & & \\
\hline & 42.49 & 8.21 & & 5.18 & $.000^{* *}$ & 2.13 & $.05^{\star *}$ & .31 \\
\hline & & & & & & & + & \\
\hline Career preferences: managerial & .50 & .23 & .17 & 2.20 & $.03^{*}$ & & & \\
\hline Career drivers: career directedness & .94 & .29 & .23 & 3.26 & $.001^{* * *}$ & & & \\
\hline
\end{tabular}

$* p \leq 0.05, * * p \leq 0.01, * * * p \leq 0.001$.

$+R^{2} \leq 0.12$ (small practical effect size), $++R^{2} \geq 0.13 \leq 0.25$ (moderate practical effect size), $+++R^{2} \geq 0.26$ (large practical effect size).

Based on the statistical results, $H 1$ (psychological career resources are significantly related to individuals' level of organizational commitment foci) is accepted.

\section{Discussion}

According to the results, participants who value the managerial career preference seem to be more strongly focused on their job, occupation and career foci. This may be attributed to the fact that these participants view upward mobility to higher positions with greater responsibility as important hence they seem to be committed to different foci.

Participants who value the freedom/autonomy career preference are more committed to occupational and career foci. According to the research findings, participants who have a greater freedom in making decisions in their organizations, will be more committed to their occupations and careers. Consistent with the line of thinking of Meyer and Gagné (2008), autonomously motivated employees employed in a work environment in which they find their jobs interesting, suited to attain personal goals or for expressing themselves may generate more positive attitudes toward their job and/or organization.

The results further indicate that participants who prefer doing activities at work in new ways by being more innovative are committed to their careers. Participants who value growth/development demonstrate commitment towards their occupations and careers. Döckel, Basson and Coetzee (2006) also found growth and development opportunities as an important retention factor that increases employees' commitment to the organization. Participants who value authority and have a high need for influence demonstrated commitment towards occupational and career foci.

Participants who feel confident about applying practical and creative skills in their career development demonstrated commitment towards occupational, career and organizational foci. In the context of careers, practical/creative skills are required to implement career options (Bay and Lim, 
2006; Coetzee, 2008). Managers should thus strive to learn about factors that affect creativity of employees and look for new drivers for continuous innovation. It is important to note that creativity depends on individual's attitude towards the organization (organizational commitment) (Hou, Gao, Wang, Li and Yu, 2011).

Employees who experience high levels of skills variety in their jobs are more likely to remain with the employing organization (De Vos and Meganck, 2007). A positive relationship was also found between skills variety and organizational commitment by Bhuian, Shammari and Jefri (1996) and Dunham, Grube and Castaned (1996). The development of practical/creative skills, self/other skills and high levels of self-esteem appears to be especially important in increasing individuals' commitment to their careers in the organization.

The results further showed that participants who can relate well to others appear to have high levels of commitment towards occupational, career and organizational foci. The findings suggest that participants who are willing to help others, know their future career goals, have plans to achieve their goals and are able to explore future opportunities seem to feel highly involved and committed towards their occupations and careers. Participants who have the skill to interact at an emotional and social level also seem to feel psychologically more connected (committed) to their organization.

Emotions experienced with regard to social networks have implications for how the information relating to career choice will be processed, which may have an effect on commitment towards the organization (Emmerling and Cherniss, 2003). Research by Sinclair (2009) indicates that people who are emotionally literate are able to form supportive social networks, which increase their sense of belonging to the organization. Participants who are able to control and show their emotions have been shown to be committed to their organization (organizational foci) (Adeyemo, 2007; Humphreys, Brunsen and Davis, 2005).

The findings suggest that the participants' high levels of self-esteem and behavioral adaptability contributed positive experiences towards their occupations and careers. Career-adaptable individuals tend to be curious and concerned about their future as an employee and are willing to take action to increase their personal control over their vocational future, and hence they may act more confident and committed regarding their occupations and careers in the organization (Savickas, 2005).

It appears from the findings that increasing participants' psychological career resources (managerial, variety/creativity, growth/development, authority/influence, practical/creative skills, career purpose, career directedness, career venturing, selfesteem, and behavioral adaptability) may assist them in proactively managing their careers and thereby enhance their commitment to their occupations and careers. It also appears from the research literature that psychological career resources highlighted in the findings may strongly influence other career or workrelated outcomes such as organizational commitment which in turn impact on the retention of staff (Meyer and Allen, 1997; Rossier Zecca, Strauffer, Maggori and Dauwalder, 2012; Savickas et al., 2009).

Participants with a strong degree of career commitment may have higher career expectations (for example, the need for variety and creativity and career directedness) and may tend to make a significant investment in their careers to uphold their career commitment which may emotionally attach them to the organization.

\section{Implications for management}

The overall findings add to the career and retention literature through identification of psychological career resources that has an impact on organizational commitment foci for retention purposes. The results suggest that favorable organizational conditions and career development support practices that provide the participants with a variety/creativity of challenging tasks they desire and that allow them to think creatively and innovatively, may help to increase their commitment to their careers in the organizations.

Organizations should create an environment in which skills can be applied in a practical and innovative manner to accomplish career goals, because once these skills are developed, feelings of satisfaction with one's career will be inevitable, leading to retention possibilities. Career development practices should also assist employees to develop the practical and creative skills they need to envision and plan their careers, and the personal and interpersonal management skills they need to manage their careers successfully in the organization.

The results further suggest that managers and human resources professional involved in staff retention should pay particular attention to career development support practices that address employees' needs for career growth and advancement opportunities and challenging work. Career development support practices could assist individuals in developing the skills and abilities that will help them to succeed in their careers. Helping individuals to understand and develop their career paths and allowing them to explore new and different career opportunities may encourage them to remain with the employing organization. 
Organizations should also have a strategy in place to help individuals to develop different psychological career resources that will inform and support them in their career decision-making process.

For retention purposes, an organization should strive to develop commitment strategies that help to shape the desired individual behavior and attitudes, which in turn generate psychological links between the organization and employee goals (Ferreira, 2012). The focus of the organization should be on developing committed employees in general who can be trusted to carry out job tasks in a way that is consistent with organizational goals (Storm and Roodt, 2002).

\section{Conclusion and recommendations}

People with a strong degree of career commitment may have higher career expectations (for example, the need for variety and creativity and career directedness) and may tend to make a significant investment in their careers to uphold their career commitment which may emotionally attach them to the organization. Since the study has been limited to participants predominantly employed in service industry in the field of industrial and organizational psychology, the findings cannot be generalized to other occupational context. Given the exploratory nature of this study, associations between participants' psychological career resources and organizational commitment foci have been interpreted rather than established. Broader samples across various occupational, race, gender and age groups and economic sectors need to be used before conclusions can be drawn about the relationship between psychological career resources and organizational commitment foci. The findings provided valuable pointers for the design of career development practices aimed at retaining valuable employees.

\section{References}

1. Adeyemo, D.A. (2007). Emotional intelligence and the relationship between job satisfaction and organizational commitment of employees in public parastatals in Oyo State, Nigeria, Pakistan Journal of Social Sciences, 4, pp. 324-330.

2. Aryee, S., Chay, Y. and Chew, J. (1994). An investigation of the predictors and outcomes of career commitment in the three career stages, Journal of Vocational Behavior, 44, pp. 1-16.

3. Bay, S.G.K. and Lim, K.M. (2006). Correlations of multiple intelligences and emotional intelligence: A closer analysis of theoretical assumptions, The Korean Journal of Thinking and Problem Solving, 16 (1), pp. 53-64.

4. Bentein, K., Vandenberghe, C., Vandenberg, R. and Stinglhamber, F. (2005). The role of change in the relationship between commitment and turnover: A latent growth modelling approach, Journal of Applied Psychology, 9 (3), pp. 468-482.

5. Bhuian, S.N.E.S., Shammari, A.I. and Jefri, O.A. (1996). Organizational commitment, job satisfaction, and job characteristics: An empirical study of expatriates in Saudi Arabia, International Journal of Commerce and Management, 6, pp. 57-80.

6. Coetzee, M. (2008). Psychological career resources of working adults: A South African survey, South African Journal of Industrial Psychology, 34 (2), pp. 10-20.

7. Cohen, A. (2003). Multiple commitments in the workplace: An integrative approach. New York: Lawrence.

8. Colarelli, S.M. and Bishop, R.C. (1990). Career commitment functions, correlates and management, Group and Organization Studies, 15 (2), pp. 158-176.

9. De Vos, A. and Meganck, A. (2007). What HR managers do versus what employees value: Exploring both parties' view on retention management from a psychological contract perspective, Personnel Review, 38 (1), pp. 45-60.

10. Dixit, V. and Bhati, M. (2012). A study about employee commitment and its impact on sustained productivity in India Auto-component Industry, European Journal of Business and Social Sciences, 1 (6), pp. 34-51.

11. Döckel, A., Basson, J.S. and Coetzee, M. (2006). The effect of retention factors on organizational commitment: An investigation of high technology employees, South African Journal of Human Resource Management, 4 (2), pp. 20-28.

12. Dunham, R.B., Grube, J.A. and Castaned, M.B. (1996). Organizational commitment: The utility of an integrative definition, Journal of Applied Psychology, 79, pp. 370-380.

13. Ebberwein, C.A., Krieshok, T.S., Ulven, J.C. and Prosser, E.C. (2004). Voices in transition: Lessons on career adaptability, Career Development Quarterly, 52 (4), pp. 292-308.

14. Emmerling, R.J. and Cherniss, C. (2003). Emotional intelligence and the career choice process, Journal of Career Assessment, 11 (2), pp. 153-167.

15. Ferreira, N. (2010). The relationship between psychological career resources and organizational commitment. Unpublished master's dissertation. University of Pretoria, Pretoria.

16. Ferreira, N. (2012). Constructing a psychological profile for staff retention. Unpublished doctoral thesis. University of South Africa, Pretoria.

17. Ferreira, N., Basson, J. and Coetzee, M. (2010). Psychological career resources in relation to organizational commitment: An exploratory study, SA Journal of Human Resources, 8 (1), pp. 284-294.

18. Fugate, M., Kinicki, A. and Ashforth, B. (2004). Employability: A psycho-social construct, its dimensions, and applications, Journal of Vocational Behavior, 65, pp. 14-38. 
19. Griffin, B. and Hesketh, B. (2005). Adaptable behaviors for successful work and career adjustment, Australian Journal of Psychology, 55 (2), pp. 65-73.

20. Hobföll, S.E. (2002). Social and psychological resources and adaptation, Review of General Psychology, 6, pp. 307-324.

21. Hou, Y.H., Gau, G., Wang, F., Li., T. and Yu, Z. (2011). Organizational Commitment and creativity: The influence of thinking styles, Annals of Economics and Finance, 12 (2), pp. 411-431.

22. Humphreys, J., Brunsen, B. and Davis, D. (2005). Emotional structure and commitment: Implications for health care management, Journal of Health Organization and Management, 19, pp. 120-129.

23. Judge, T.A. and Ferris, G.R. (1992). The elusive criterion of fit in human resource staffing decisions, Journal of Business Ethics, 15, pp. 47-67.

24. Kim, N. (2005). Organizational interventions influencing employee career development preferred by different career success orientations, International Journal of Training and Development, 9 (1), pp. 47-61.

25. Lee, K., Carswell, J.J. and Allen, N.J. (2000). A meta-analytic review of occupational commitment: Relations with person- and work-related variables, Journal of Applied Psychology, 85, pp. 799-811.

26. Lumley, E. (2009). Exploring the relationship between career anchors, job satisfaction and organizational commitment. Unpublished masters dissertation. University of South Africa, Pretoria.

27. Mahal, P.K. (2012). HR practices as the determinants of organizational commitment and employee retention, Journal of Management Research, 11 (3).

28. Mallol, C., Holtom, B. and Lee, T. (2007). Job embeddedness in a culturally diverse environment, Journal of Business Psychology, 22, pp. 35-44.

29. May, M., Werner, A. and Theron, A. (2014). The influence of perceptions of organizational trust and fairness on employee citizenship, Problems and Perspectives in Management, 12 (3), pp. 99-105.

30. McArdle, S., Waters, L., Briscoe, J.P. and Hall, D.T. (2007). Employability during unemployment: Adaptability, career identity and human and social capital, Journal of Vocational Behavior, 71, pp. 247-264.

31. Meyer, J.P. and Allen, N.J. (1997). Commitment in the workplace: Theory, research and application. Thousand Oaks, CA: Sage.

32. Meyer, J.P. and Gagné, M. (2008). Employee engagement from a self-determination theory perspective, Industrial and Organizational Psychology, 1, pp. 60-62.

33. Mueller, C.W., Wallace, J.E. and Prince, J.L. (1992). Employee commitment, Work and Occupations, 9 (3), pp. 211-236.

34. Noodin, A., Williams, T. and Zimmer, C. (2002). Career commitment in collectivist and individualist cultures: A comparative study, International Journal of Human Resources Management, 13 (1), pp. 35-54.

35. Peterson, D.K. (2003). The relationship between ethical pressure, relativistic moral beliefs and organizational commitment, Journal of Managerial Psychology, 18 (6), pp. 57-572.

36. Pretorius, A.A.S. and Roodt, G. (2004). Die verband tussen werknemertevredenheid en organisasieverbondenheid, SA Journal of Industrial Psychology, 30 (3), pp. 65-74.

37. Roodt, G. (1997). Theoretical and empirical linkages between work-related commitment foci, SA Journal of Industrial Psychology, 23 (2), pp. 6-13.

38. Roodt, G. (2004). Concept redundancy and contamination in employee commitment research: Current problems and future directions, SA Journal of Industrial Psychology, 30 (1), pp. 82-90.

39. Rossier, J., Zecca, G., Stauffer, S.D., Maggiori, C. and Dauwalder, J. (2012). Career Adapt-Abilities Scale in a French-speaking Swiss sample: Psychometric properties and relationships to personality and work engagement, Journal of Vocational Behavior, 80, pp. 734-743.

40. Savickas, M. (2005). The theory and practice of career construction. In Brown, S.D. and Lent, R.W. (eds.), Career development and counselling: Putting theory and research to work. Canada: John Wiley and Sons, Inc.

41. Savickas, M.L. (2011). New questions for vocational psychology: Premises, paradigms, and practices, Journal of Career Assessment, 19 (3), pp. 251-258.

42. Savickas, M.L., Nota, L., Rossier, J., Dauwalder, J.P., Duarte, M.E. and Guichard, J. (2009). Life designing: A paradigm for career construction in the $21^{\text {st }}$ century, Journal of Vocational Behavior, 75, pp. 239-250.

43. Schneider, B., Goldstein, H.W. and Smith, D.B. (1995). The ASA framework: An update, Personnel Psychology, 48, pp. 747-773.

44. Sinclair, V. (2009). Experiencing career satisfaction and career success over the life span. Available at: http://www.counselling-directory.org.uk/counselloradvice98889.html. Accessed 2 February 2010.

45. Storm, L. and Roodt, G. (2002). Die verband tussen organisasiesosialisering en organisasieverbondenheid, Tydskrif vir Bedryfsielkunde, 28 (1), pp. 14-21.

46. Valentine, S., Godkin, L. and Lucero, M. (2002). Ethical context, organizational commitment and personorganization fit, Journal of Business Ethics, 41, pp. 349-360.

47. Van der Heijde, C.M. and Van der Heijden, B.I.J.M. (2006). A competence-based and multidimensional operationalisation of employability, Human Resource Management, 45 (3), pp. 449-476.

48. Wasti, S.A. and Onder, C. (2009). Commitment across cultures: Progress, pitfalls and propositions. In H.J. Klein, T.E. Becker \& J.P. Meyer (Eds), Commitment in organizations: Accumulated wisdom and new directions. New York: Routledge Taylor and Francis Group, pp. 309-343. 